\title{
Social Smoking by University of California, Santa Cruz Students
}

\author{
Mike Males \\ University of California, Santa Cruz
}

\begin{abstract}
While many health interests worry about persistently high rates of cigarette smoking among college students, little research has tracked qualitative changes in student habits such as "social smoking." A survey of 670 University of California, Santa Cruz, undergraduate students ages 18-43, mean age 20.6, found $57 \%$ of the weighted sample smoked cigarettes in the past year, compared to $37 \%$ of college undergraduates nationally and 34\% of UCSC students' parents. However, two-thirds of UCSC student smokers smoke socially (less than daily), compared to $60 \%$ of student smokers nationally and $16 \%$ of parent smokers. Half of UCSC social smokers report smoking less than an entire cigarette per occasion and $70 \%$ report smoking less today than in the past; the fraction who smoke heavily tend to have parents who smoke heavily. Students' reports indicating their social smoking is an equilibrium behavior unlikely to lead to heavier smoking need longitudinal investigation.
\end{abstract}

(C) 2007 Californian Journal of Health Promotion. All rights reserved.

Keywords: tobacco, smoking, social smoking, college students

\section{Introduction}

Concern has been expressed that college students ages 18-24 show the highest rates of cigarette smoking today, as well as lesser declines in cigarette smoking over the last 25 years, compared to younger teens and older adults. Monitoring the Future (Johnston, O’Malley \& Schulenberg, 1980-2004) finds the percentage of college students one to four years beyond high school who reported smoking cigarettes in the previous year or previous month in 2004 was virtually the same as in the first survey in 1980 (Appendix A). However, bigger drops were recorded in college students' daily smoking, especially heavier (half a pack or more) daily smoking.

Persistent high smoking rates among these young, well-educated populations together with standard assumptions about nicotine's addictiveness create apprehensions of a future smoking revival. However, there are indications that today's smoking among high school seniors and college students differs qualitatively from past patterns. In 1980, 51\% of college students who smoked at all smoked daily and 35\% smoked heavily; in 2004, just 38\% and 19\%, respectively (Johnston, O’Malley \& Schulenberg, 1980-2005). High school and college students' smoking, once dominated by daily use, increasingly is dominated by episodic weekend or occasional "social" use.

Students" trend toward "social smoking" is poorly understood (Moran, Wechsler \& Rigotti, 2004). Some health experts regard it as a stable behavior but argue true social smoking is rare (University Health Center, 2005), while others view it as a stage among college students who smoke cigarettes occasionally in connection with drinking alcohol and socializing (Hines, Fretz \& Nollen, 1998). Others believe college students' social smoking "may represent a stage in the uptake of smoking" (Moran, Wechsler \& Rigotti, 2004, p. 1033) and "can wind up as a lifelong problem" (Office of Health Education, 2005). A California Department of Health Services anti-smoking ad declares that young "social smokers" will progress rapidly to pack-aday smokers. 
Table 1

National smoking trends among US young adults, 2004 vs. 1980/85

(College students one to four years beyond high school).*

\begin{tabular}{|l|c|c|c|c|}
\hline \multicolumn{1}{|c|}{ Year } & \multicolumn{2}{|c|}{} & \\
\hline Smoking Trends & $\mathbf{1 9 8 0}(\mathbf{\% )}$ & $\mathbf{1 9 8 5} \mathbf{( \% )}$ & $\mathbf{2 0 0 4} \mathbf{( \% )}$ & \% Change \\
\hline Smoked cigarette in most recent & & & & \\
\hline year & 36.2 & & 36.7 & +1 \\
\hline month & 25.8 & & 24.3 & -6 \\
\hline day & & & & \\
\hline half-pack or more per day & 12.7 & & 6.8 & -46 \\
\hline Smoked cigarette in most recent month & & & & \\
\hline high school seniors & & 30.1 & 25.0 & -17 \\
\hline age 18-21, college only & & 22.4 & 24.3 & +8 \\
\hline
\end{tabular}

* Sources: Johnston, O’Malley \& Schulenberg, 1980-2005

\section{Data and Methods}

This study examines smoking behaviors and trends among 670 University of California, Santa Cruz, undergraduate students in 13 sociology classes from 2003 to 2006. The brief survey, completed anonymously, asked students whether they smoked a tobacco cigarette in the previous year (light social smokers), month (monthly social), or day (daily), or more than 10 cigarettes in the previous day (heavy daily); whether they smoked the entire cigarette at one time or only part of it; and whether they smoked more, less, or the same as in the recent past (Appendix A). Students were asked similar questions about their parents' smoking. The students sampled ranged in age from 18 to 43, with a mean age of 20.6 years; $27 \%$ were $18-19$ years old, 53\% were $20-21,15 \%$ were $22-24$, and $5 \%$ were over age 25 . Nearly two-thirds were female. By residence, 95\% were from California, evenly split between the San Francisco Bay Area and elsewhere.

\section{Results}

Contrary to expectations, UCSC students had significantly higher rates of smoking within the previous year than students in nationwide surveys or than their parents (Table 2). However, two-thirds of smoking among UCSC students today is social rather than daily, compared to $60 \%$ of smoking by students nationally in 2004, half of student smoking in 1980 , and just $16 \%$ of smoking by their parents (Table 3).

Table 2

Prevalence of cigarette smoking among college students, US and UC, Santa Cruz, 1980-2005

\begin{tabular}{|c|c|c|c|c|c|c|}
\hline & \multirow[t]{2}{*}{$\mathbf{N}$} & \multirow{2}{*}{$\begin{array}{c}\text { Smoked in } \\
\text { Past Year } \\
(\%)\end{array}$} & \multicolumn{2}{|c|}{$\begin{array}{c}\text { Social Smoker, } \\
\text { past year }\end{array}$} & \multicolumn{2}{|c|}{$\begin{array}{c}\text { Daily } \\
\text { Smoker }\end{array}$} \\
\hline & & & $\begin{array}{c}<\text { Monthly } \\
\text { (\%) }\end{array}$ & $\begin{array}{c}\text { > Monthly } \\
\text { (\%) }\end{array}$ & $\begin{array}{c}<10 \text { Cigs. } \\
(\%)\end{array}$ & $\begin{array}{c}>10 \text { cigs. } \\
(\%)\end{array}$ \\
\hline \multicolumn{7}{|c|}{ National college vs. UCSC smoking trends, ages 18-21 } \\
\hline National & 1,400 & 36.7 & 12.4 & 10.5 & 7.0 & 6.8 \\
\hline UCSC (wtd.) & 536 & 55.7 & 17.3 & 20.9 & 14.0 & 3.6 \\
\hline \multicolumn{7}{|c|}{ UCSC smoking (2004-2006), whole student sample } \\
\hline UCSC (raw) & 670 & 57.5 & 17.8 & 20.7 & 14.6 & 4.5 \\
\hline UCSC (wtd.) & 670 & 56.7 & 17.5 & 20.7 & 14.2 & 4.3 \\
\hline
\end{tabular}




\begin{tabular}{|c|c|c|c|c|c|c|}
\hline & \multirow[t]{2}{*}{$\mathbf{N}$} & \multirow{2}{*}{$\begin{array}{c}\begin{array}{c}\text { Smoked in } \\
\text { Past Year }\end{array} \\
(\%)\end{array}$} & \multicolumn{2}{|c|}{$\begin{array}{c}\text { Social Smoker, } \\
\text { past year }\end{array}$} & \multicolumn{2}{|c|}{$\begin{array}{c}\text { Daily } \\
\text { Smoker }\end{array}$} \\
\hline & & & $\begin{array}{c}<\text { Monthly } \\
\text { (\%) }\end{array}$ & $\begin{array}{c}\text { > Monthly } \\
\text { (\%) }\end{array}$ & $\begin{array}{c}<10 \text { Cigs. } \\
(\%)\end{array}$ & $\begin{array}{c}>10 \text { cigs. } \\
(\%)\end{array}$ \\
\hline \multicolumn{7}{|l|}{ Gender } \\
\hline Male & 234 & 62.8 & 18.4 & 20.9 & 17.5 & 6.0 \\
\hline Female & 436 & 54.6 & 17.4 & 20.6 & 13.1 & 3.7 \\
\hline \multicolumn{7}{|l|}{ Age Groups } \\
\hline 18-19 years & 182 & 49.5 & 15.4 & 20.3 & 11.0 & 2.7 \\
\hline 20-21 years & 354 & 59.9 & 18.6 & 21.5 & 15.8 & 4.2 \\
\hline $22+$ years & 134 & 61.9 & 18.7 & 19.4 & 16.4 & 7.5 \\
\hline \multicolumn{7}{|l|}{ Other } \\
\hline Parents who smoke & 334 & 32.0 & 2.4 & 3.0 & 16.2 & 10.5 \\
\hline
\end{tabular}

Sources: Johnston, O’Malley \& Schulenberg (1980-2005), of college students 1-4 years after high school (2004). UCSC sample is from author's survey, students ages 18-21, 2004-06, weighted by national proportions by age and sex of full-time college students ages 18-21 in degree-granting institutions, 2004.

${ }^{*} \mathrm{p}<.01 ; * * \mathrm{p}<.001$

Table 3

Social (less than daily) smokers among UCSC students, their parents, and students nationally over time

\begin{tabular}{|l|c|c|c|c|}
\hline \multicolumn{1}{|c|}{ Generation } & \multicolumn{3}{|c|}{ Percent who smoke } & $\begin{array}{c}\text { Percent of smokers who only } \\
\text { smoke socially }\end{array}$ \\
\hline & Social & Daily & $\mathbf{1 0 + / \text { day }}$ & \\
\hline UCSC 18-21, 2004-2006 & 38.2 & 17.6 & 3.6 & 68.5 \\
\hline MTF, 2004 & 22.9 & 13.8 & 6.8 & 62.4 \\
\hline MTF, 1980 & 17.9 & 18.3 & 12.7 & 49.4 \\
\hline UCSC parent & 5.4 & 26.7 & 10.5 & 16.8 \\
\hline
\end{tabular}

Sources: Johnston, O’Malley \& Schulenberg (1980-2005), college students 1-4 years beyond high school; author’s survey, 2004-2006.

Further, nearly half of UCSC's social smokers, including $64 \%$ of occasional social smokers, report smoking only part of the cigarette when they smoke. Social smokers' comments on surveys indicate that passing a cigarette around a group is a common practice. Large majorities of social smokers report that they smoke less today than in the past; only 5\% report smoking more today. Heavier daily smokers show the opposite trend-nearly all say they smoke the entire cigarette, and $40 \%$ say their smoking has increased in recent years (Table 4).

Table 4

Intensity and trend in smoking among UCSC social (less than daily) smokers

\begin{tabular}{|c|c|c|c|c|c|}
\hline Smoking Trend & N & Smoke only part of cig. (\%) & \multicolumn{3}{|c|}{ Smoking today compared to past (\%) } \\
\hline & & & More & Same & Less \\
\hline All social & 258 & 46.9 & 5.0 & 22.9 & 72.1 \\
\hline$<1 /$ month & 119 & 63.9 & 0.8 & 18.5 & 80.7 \\
\hline$>1$ /month & 139 & 32.4 & 8.6 & 26.6 & 64.8 \\
\hline Daily & 128 & 22.7 & 30.5 & 21.1 & 48.4 \\
\hline$<10$ cigs/day & 98 & 27.6 & 27.6 & 17.3 & 55.1 \\
\hline$>10$ cigs/day & 30 & 6.7 & 40.0 & 33.3 & 26.7 \\
\hline
\end{tabular}

Source: author’s survey, 2004-2006. 
Student smoking even as late as college remains strongly and linearly related to whether their parents smoke (Table 5). Students whose parents never smoked are nearly twice as likely to be nonsmokers themselves. Although two-thirds of the small number of students with social- smoking parents were social smokers themselves, parents' smoking habits overall do not predict students' social smoking. However, parents' heavier daily smoking habits are strongly related to students' daily — and, especially, heavy daily — smoking.

Table 5

UCSC student smoking status by parent smoking status

\begin{tabular}{|c|c|c|c|}
\hline & $\begin{array}{c}\text { Parent never smoked } \\
\mathbf{( \% )}(\mathbf{N}=\mathbf{1 7 3})\end{array}$ & $\begin{array}{c}\text { Percent of parents is } \\
\text { heavy daily smoker (\%) } \\
(\mathbf{N = 3 5 )}\end{array}$ & O.R. \\
\hline Student is: & & & \\
\hline Nonsmoker & 50.3 & 34.3 & $0.52^{*}$ \\
\hline Social smoker & 37.0 & 34.3 & 0.89 \\
\hline Daily smoker & 10.4 & 31.4 & $3.94^{* *}$ \\
\hline Heavy daily smoker & 2.3 & 17.1 & $8.76^{* *}$ \\
\hline
\end{tabular}

Source: author's survey, 2004-06. ${ }^{*} \mathrm{p}=.05 ;{ }^{* *} \mathrm{p}<.01$

Compared to students with never-smoking parents, the few with parents who smoke heavily are nearly nine times more likely to be heavy daily smokers.

\section{Discussion}

University of California, Santa Cruz, students appear to have evolved a widespread pattern of lighter cigarette smoking. UCSC students report smoking cigarettes socially at much higher rates, smoking heavily at much lower rates, and smoking less than the whole cigarette than their parents do. The small number of parent social smokers, the large number of student social smokers, and the lack of correlation between parent smoking status and student social smoking status suggest social smoking is incubated in modern high school and college environments. Conversely, the few UCSC students most at risk for future heavy smoking have heavy-smoking parents and have progressed to daily smoking themselves.

Two questions arise: First, does students' "social smoking" represent a new trend toward lighter, non-addictive smoking that promises to reduce cigarette consumption and health injury? Bjartveit and Tverdal (2005) find that compared to smokers of 25 or more cigarettes per day, those who smoke 1-4 cigarettes per day experienced reduced relative risks of ischemic heart disease of $20 \%$, cancer (60\%), lung cancer (90\%), and mortality (50\%). However, they also found that compared to nonsmokers, light daily smokers suffered significantly higher rates of lung cancer and ischemic heart disease, slightly higher rates of cancer, and higher rates of overall mortality. The dose-response effect found suggests that smoking less than daily would further reduce the hazards of smoking, though not to zero.

Second, is social smoking among college students a stable, equilibrium habit or simply the precursor to heavy daily smoking, albeit commencing at older ages than in the past? This cross-sectional study is inadequate to assess that question; in fact, it provides evidence for both views. Older UCSC students report similar rates of social smoking but higher rates of daily (including heavy daily) smoking than do younger students (Table 2). However, a large majority of current UCSC social smokers report smoking less (72\%) or the same amount (23\%) now than in the past; only a small fraction (5\%) report smoking more (Table 4). 
These seemingly contradictory findings can be reconciled if Table 2's higher daily smoking rate among older students is attributed to generational effects (that is, older generations are more likely to smoke daily, on a continuum from past generations) rather than developmental effects (that is, younger light smokers tend to evolve into older heavy smokers). If the effects observed are largely generational, we would expect follow-up studies to find today's UCSC 18-19 year-old social smokers are not taking up daily smoking at the levels found among today's UCSC over-21 students. If social smoking is indeed a generational trend, it is likely to be stable and to predict much lower levels of cigarette consumption and smoking-related morbidity and mortality in the future among these student populations.
Health educators and policy makers are understandably reluctant to promote any form of tobacco use (University Health Center, 2005; Office of Health Education, 2005). Fortunately, many measures that deter smoking, such as raised taxes on tobacco and smoke-free campuses and other locales (Bratton \& Trieu, 2005) may also deter addictive smoking by adding to its cost and inconvenience. Further longitudinal study of the conditions that preserve lighter social smoking as an equilibrium habit or a precursor to smoking cessation, versus the conditions that promote transition from social smoking to addictive smoking, is needed before policies to address social smoking can be refined.

\section{References}

Bjartveit, K., \& Tverdal, A. (2005). Health consequences of smoking 1-4 cigarettes a day. Tobacco Control, 14(5), 315-320.

Bratton, S., \& Trieu, S. (2005). Tobacco control: A case study at a California community college. Californian Journal of Health Promotion, 3(3), 61-72.

Hines, D., Fretz, A., \& Nollen, N. (1998). Regular and occasional smoking by college students: personality attributions of smokers and nonsmokers. Psychology Reports, 83, 1299-130.

Johnston, L., O’Malley, P. \& Schulenberg, J. (1980-2005). Monitoring the Future national survey results on drug use, 1980-2005: Volume II, College students and adults ages 18-45 (NIH Publication No. 04-5508). Bethesda, MD: National Institute on Drug Abuse.

Moran, S., Wechsler, H., \& Rigotti, N. (2004). Social smoking among US college students. Pediatrics, 114, 1028-1034.

Office of Health Education, University of Pennsylvania. (2005). Can you get away with social smoking? Retrieved September 15, 2005, from http://www.vpul.upenn.edu/ohe/library/drugs/smoking/social-smoking.htm

University Health Center, University of Maryland, (2005). Social smoking. Retrieved September 15, 2005, from http://www.health.umd.edu/programs/terps quit/myths.php

\section{Author Information}

Mike A. Males, Ph.D.

Sociology Department

University of California, Santa Cruz

Santa Cruz, CA 95064 


\section{Appendix A}

\section{Smoking survey administered to University of California, Santa Cruz, students}

Male__ Female

Age

1. Anonymous smoking survey (refers to TOBACCO only). Please check ONE answer:

In the last year, I did NOT smoke cigarettes at all.

I smoked at least one cigarette in the past YEAR, but none in the past month.

— I smoked at least one cigarette in the past MONTH, but none in the past 24 hours.

_ I I smoked at least one cigarette, but fewer than 10 cigarettes, in the last 24 hours.

_ I I smoked 10 or more cigarettes in the past 24 hours.

2. If you smoke cigarettes at all, do you typically:

_ smoke the ENTIRE cigarette? or

_ smoke only PART of the cigarette (if only part, is it because you usually share it with others, or throw away or save the unsmoked part unfinished)?

3. Compared to the past time when you smoked the most, do you smoke MORE _ , or FEWER cigarettes now than you used to, or around the SAME number ?

4. When you were growing up, did your parents (including stepparents, foster parents, parents' partners, etc.) smoke cigarettes?

- Yes, one did

- Yes, both did

- No

Comments 